\title{
Teleostei, Scophthalmidae: four-spot megrim spotted in Norwegian waters
}

\author{
Rupert Wienerroither', Otte Bjelland', Gjertrud Jensen' and Anne Kari Sveistrup ${ }^{2}$
}

\begin{abstract}
Wienerroither R, Bjelland O, Jensen G, Sveistrup AK. 2019. Teleostei, Scophthalmidae: four-spot megrim spotted in Norwegian waters. Fauna norvegica 39: 26-29.

The flatfish four-spot megrim (Lepidorhombus boscii) was registered in Norwegian waters, both in trawl catches and video observations. The records represent a considerable northward extension of the species. Specimens of up to $49 \mathrm{~cm}$ were measured, representing also a new maximum size for this species. The number of registrations has increased within the last years, indicating that the species got more common in this area.
\end{abstract}

doi: 10.5324/fn.v39i0.2872. Received: 2018-11-30. Accepted: 2019-02-11. Published online: 2019-03-21. ISSN: $1891-5396$ (electronic).

Keywords: Lepidorhombus, boscii, whiffiagonis, new records, range

1. Institute of Marine Research, PO box 1870 Nordnes, NO-5817 Bergen, Norway

2. Institute of Marine Research, Framsenteret, PO box 66606 Langnes, NO-9296 Tromsø, Norway

Corresponding author: Rupert Wienerroither

E-mail: rupert@hi.no

\section{INTRODUCTION}

Scophthalmidae (turbots, megrims, and brills) is a family of flatfishes with three genera and eight species (Chanet 2003, Fricke et al. 2018), seven of which are occurring in the eastern North Atlantic, five are previously known from Norwegian waters (Nielsen 1986, Pethon 2005). They are characterized by a clearly visible preoperculum with a free margin, the absence of a spine in the elongate and equally long pelvic fin bases, the presence of a lateral line on both sides, and the location of both eyes on the left side (Nielsen 1986). Genus Lepidorhombus has pelvic fins free from the anal fin, ctenoid scales on the eyed and cycloid scales on the blind side, as well as a toothed vomer (Nielsen 1986). There are two species in the genus, the megrim Lepidorhombus whiffiagonis (Walbaum, 1792) and the four-spot megrim L. boscii (Risso, 1810). They differ in morphology and coloration: in $L$. boscii the snout is shorter than the eye diameter (longer in L. whiffiagonis) and it has two very distinct black spots posterior on both the dorsal and the anal fin (Nielsen
1986, Pethon 2005, Robson et al. 2005). Although the median fins of $L$. whiffiagonis can be speckled, these spots are never so distinct and clearly marked as in $L$. boscii.

Four-spot megrim is a deepwater species found along the continental edge down to $800-1000 \mathrm{~m}$ depth on soft bottom, most common between 275 and $640 \mathrm{~m}$, sometimes even pelagic (Nielsen 1986, Pethon 2005). It reaches a total length of about $44 \mathrm{~cm}$ but is rarely larger than $32 \mathrm{~cm}$ (Nielsen 1986, Pethon 2005, Munroe \& Chanet 2016), sexual maturity occurs at 3-4 years of age, females can live up to at least 13 years, males to 11 years, females grow faster and larger than males (Robson et al. 2000, Landa et al. 2002, Landa \& Fontenla 2016, Munroe \& Chanet 2016), but growth rates vary also with area (Landa et al. 2002). Spawning is not well known but may occur along the outer continental shelf margin at considerable depths (Munroe \& Chanet 2016), known nursery areas are in the Celtic Sea and on the Porcupine Bank (Dransfeld et al. 2004). Until now its distribution was indicated from Cape Bojador in the south, the Mediterranean, and northward to the British Isles (Nielsen 1986), west of the Faeroes (Pethon 2005), and southern Iceland 


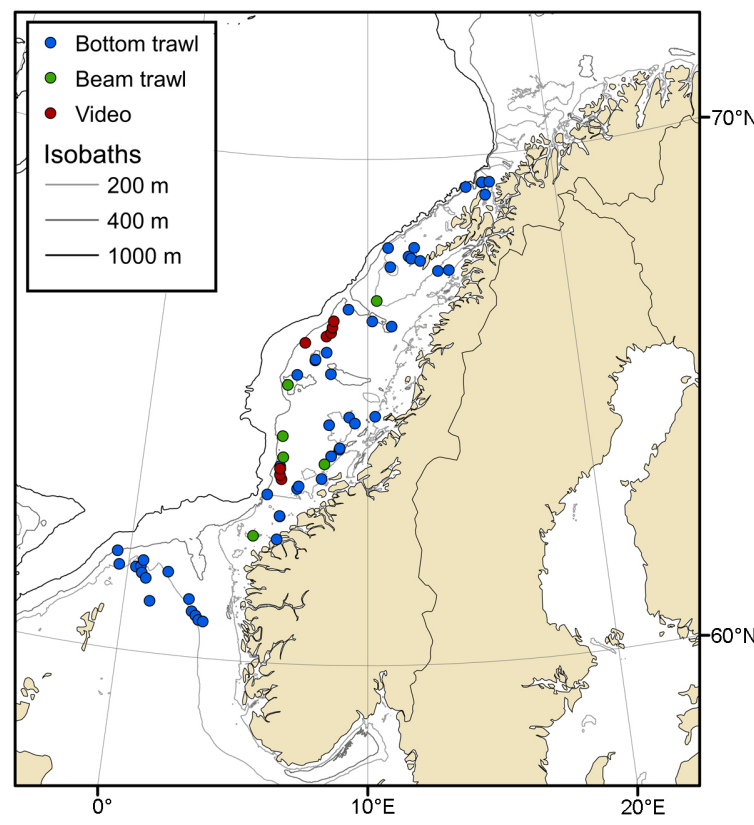

Figure I. Map showing the registrations of Lepidorhombus boscii from 1995-2018, abundance per station not indicated.

(Jónsson and Pálsson 2013). However, although Velasco et al. (2015) report only two specimens from the northern North Sea, it was repeatedly found further north along the continental slope off Norway.

We report here these records and discuss the distribution of the species in northern waters.

\section{MATERIAL AND METHODS}

The fishes were obtained during different surveys conducted by the Institute of Marine Research (IMR), Norway. Fishery independent surveys for population monitoring in the North Sea and along the Norwegian coast use different types of bottom trawls (e.g. Campelen shrimp trawl, Alfredo cod trawl) with varying ground gear and mesh sizes. The specimens caught were identified and measured at sea, some of them frozen as vouchers. The MAREANO-project, which maps benthic organisms and bottom conditions off the Norwegian coast (www.mareano.no), used a beam trawl (horizontal opening 2 $\mathrm{m}$, mesh width $4 \mathrm{~mm}$, towed on the bottom for $5 \mathrm{~min}$ at a speed of 1.5 knots) to sample benthic organisms. All fishes from the beam trawl were frozen for later identification at land. Some specimens were subsequently transferred to the University Museum of Bergen where they are kept in $75 \%$ ethanol for permanent storage. In addition to trawl catches, during the MAREANO surveys four-spot megrim was also recorded by video footage taken by IMR's video platform Campod, a tripod equipped with a high-definition video camera (SONY HDC$\mathrm{X} 300$ ) and lights (Buhl-Mortensen et al. 2009). The camera has a manual zoom and focus and is mounted on a pan-and-tilt

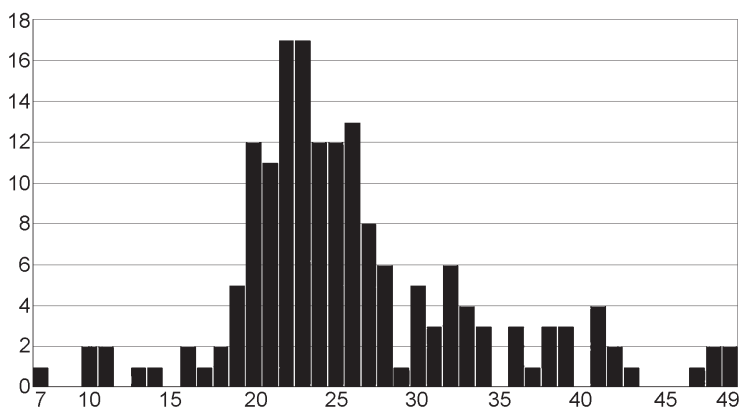

Figure 2. Length distribution of the 169 specimens of Lepidorhombus boscii, $\mathrm{x}$-axis: total length in $\mathrm{cm}, \mathrm{y}$-axis: number of specimens.

device. For the present observations the Campod was towed 1.5 meters above the seabed at a speed of 0.7 knots (BuhlMortensen et al. 2009).

Locality and length-data on all Lepidorhombus boscii were extracted from the IMR database. CTD data were available for 26 stations.

\section{RESULTS}

In the years 1995-2018, 195 specimens of $L$. boscii were caught, registered and verified or considered valid. The specimens were caught at 51 bottom trawl and six beam trawl stations (Figure 1). Depths varied from 90 to $497 \mathrm{~m}$, most specimens (35\%) were caught in $200-250 \mathrm{~m}$ depth. Temperatures varied from 6.3 to $10.9^{\circ} \mathrm{C}$, and salinity from 34.05 to $35.38 \%$. The northernmost record was taken in October 2016 at $69^{\circ} 27.1^{\prime} \mathrm{N} 16^{\circ} 10^{\prime} \mathrm{E}$ (ZMUB 23814). The highest abundance at one station was registered in March 2018 at $68^{\circ} 01.4^{\prime} \mathrm{N} 12^{\circ} 13,9^{\prime} \mathrm{E}$ with 24 specimens after 15 min trawling. Total length was recorded for 169 specimens, ranging from 7-49 $\mathrm{cm}$ (Figure 2). Five specimens were larger than $44 \mathrm{~cm}$ (Figure 2 and 3, ZMUB 23815), the previously accepted maximum size of this species. Specimens of the congener $L$. whiffiagonis were registered at 20 of the 51 bottom trawl stations.

During two surveys in June 2014 and August/September 2015, 13 specimens were recorded on video (Figure 1 and 4). Bottom depth was between 245-362 m, temperature between $7.5-8.0{ }^{\circ} \mathrm{C}$, and salinity between $35.20-35.23 \%$. The bottom substrate registered during the video transects was muddy sand, gravelly muddy sand, and sandy mud (www.mareano.no).

\section{DISCUSSION}

The present records are the northernmost occurrences ever reported for this species, including the first records from the Norwegian shelf and from north of the Arctic circle. They represent a significant range extension for the species of about 


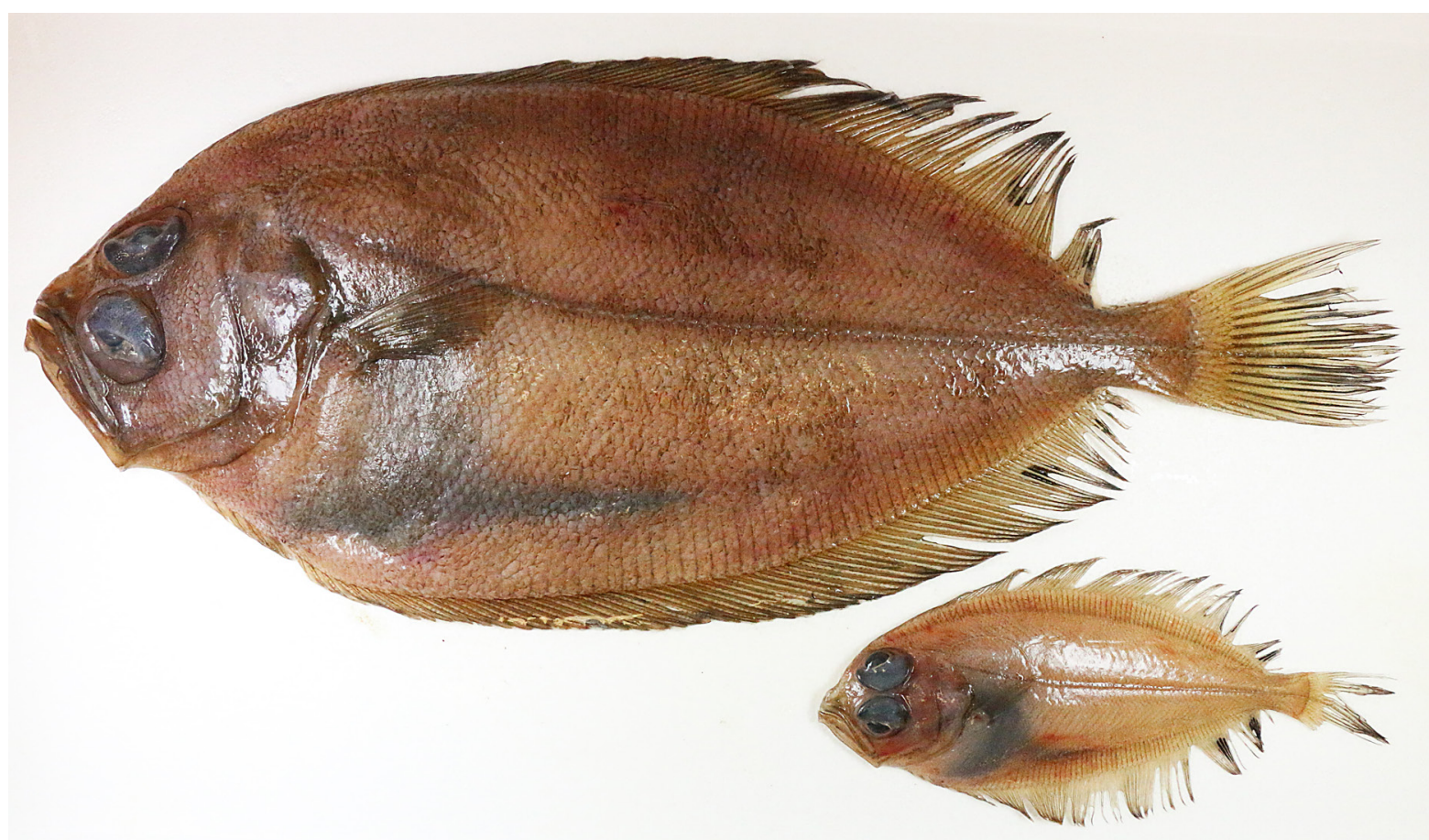

Figure. 3. Lepidorhombus boscii obtained at trawl station 55114, 6 November 2018, 6330.62'N 6 ${ }^{\circ} 57.97^{\prime} \mathrm{E}, 287 \mathrm{~m}$ depth, 48.5 and $21 \mathrm{~cm}$ TL, ZMUB 23815. Picture taken from frozen specimens, typical damages of fins and fin membranes due to trawling and handling. Photo: Rupert Wienerroither.

$1,400 \mathrm{~km}$ to the northeast (Pethon 2005). Between 1995 and 2010 only 15 specimens have been registered (ranging from 13-49 cm), and in the years 2011-2017 the average annual catch was around 15 specimens (beam trawl and video observations not included). In 2018 the registrations increased considerably, and 67 specimens (ranging from 7-48 cm) were caught. Despite this increase in number of specimens registered, there is no consecutive northward range extension recognizable. Already the first 15 specimens (found at 8 stations in the years 19952008) were distributed from 62 to $68^{\circ} \mathrm{N}$. Neither can there be seen a clear trend in the length distribution. Trawling effort and method as well as area of coverage haven't changed significantly in these years, so the expanded area of distribution as well as the rise in abundance are likely to reflect the real situation. However, in the last 10-20 years the focus on species identification at IMR vessels has increased, and former misidentifications with megrim L. whiffiagonis cannot be completely excluded. Megrim is found in the same area, but also further north and south in the shallower Barents Sea and North Sea, respectively. It is also much more common, with more than 70,000 specimens having been registered in the IMR-database since 1972 at more than 5,000 stations in the same area, plus the Barents and North Sea.

The range extension northward in Norwegian waters is in accordance with the situation in Iceland. Four-spot megrim was registered there for the first time in 2008. It is now found south and southwest of the island in 140-180 m depth (Jónsson and Pálsson 2013).

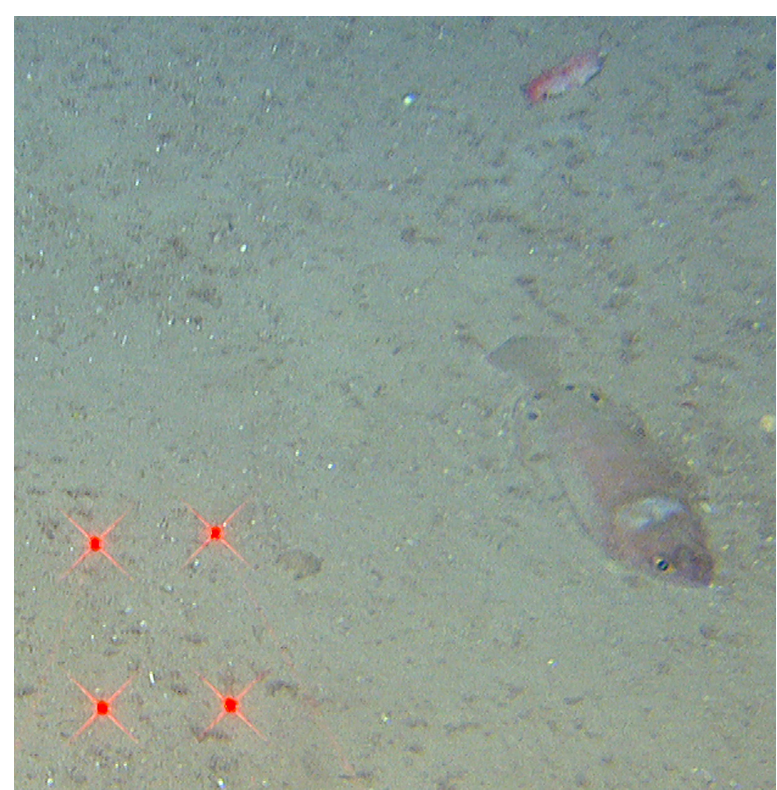

Figure 4. Lepidorhombus boscii recorded during MAREANO video transect R1566VL1615, 1 September 2015, 66 39.95’N 8¹7.28’E, $282 \mathrm{~m}$ depth. Red laser points are $10 \mathrm{~cm}$ apart. 
During the two MAREANO surveys lasting for 11 and 21 days, the video observations of the species were spatially (Figure 1) and temporally (two and three days, respectively) close together. This, and the trawl haul from March 2018 described above, indicate that the species might be quite abundant locally.

There are no north-south or seasonal trends in depth or length distribution discernable. Most specimens were caught in 200-250 m depth, but this might rather reflect IMRs prevailing trawling depth than species preferences. In the Celtic Sea it is most abundant between 250 and $400 \mathrm{~m}$ (Velasco et al. 2015). Size varied significantly within the stations, the largest ones being caught together with the more common sizes (Figures 2 and 3). The species is of no commercial interest in Norwegian waters, hence neither sexing, staging or aging was done during the surveys. Therefore, it is difficult to say why the species grows larger in Norwegian waters.

The fishes reported by us were found during all seasons and, apart from the smallest ones, in all sizes, even raising the maximum length of the species. This might indicate that the species has built a resident population in Norwegian waters. Sánchez et al. (1998) found that on the northern Spanish shelf juveniles of both Lepidorhombus-species occupy deeper water and a narrower depth range than adults. This might explain why no juveniles or larvae have been found yet, as the mesh size of the trawling gear used in these depths is too large.

\section{ACKNOWLEDGEMENTS}

We are grateful to colleagues at IMR for collecting the specimens and to two anonymous reviewers for their valuable comments on the manuscript.

\section{REFERENCES}

Buhl-Mortensen P, Dolan M, Buhl-Mortensen L. 2009. Prediction of benthic biotopes on a Norwegian offshore bank using a combination of multivariate analysis and GIS classification. ICES Journal of Marine Science 66: 2026-2032. doi: 10.1093/ icesjms/fsp200

Chanet B. 2003. Interrelationships of scophthalmid fishes (Pleuronectiformes: Scophthalmidae). Cybium 27(4): 275-286.

Dransfeld L, Dwane O, McCarney C, Kelly CJ, Danilowicz BS, Fives JM. 2004. Larval distribution of commercial fish species in waters around Ireland. Irish Fisheries Investigation 13, 39 pp.

Fricke R, Eschmeyer WN, van der Laan R (eds). 2018. Catalog of Fishes: Genera, Species, References. <http://researcharchive. calacademy.org/research/ichthyology/catalog/fishcatmain.asp>. Accessed 2018-09-27.

Jónsson G, Pálsson J. 2013. Íslenskir fiskar. Mál og menning. $493 \mathrm{p}$.

Landa J, Pérez N, Piñeiro C. 2002. Growth patterns of the four spot megrim (Lepidorhombus boscii) in the northeast Atlantic.
Fisheries Research 55: 141-152.

Landa J, Fontenla J. 2016. Age and growth of four spot megrim (Lepidorhombus boscii) in the northern Iberian waters corroborated by cohort tracking. Estuarine, Coastal and Shelf Science 179: 181-188. doi: 10.1016/j.ecss.2016.01.010

Munroe TA, Chanet B. 2016. Scophthalmidae. Turbots, megrims, brills. In: Carpenter KE, De Angelis N. (eds). The living marine resources of the Eastern Central Atlantic. Volume 4: Bony fishes part 2 (Perciformes to Tetraodontiformes) and Sea turtles. FAO Species Identification Guide for Fishery Purposes, Rome, FAO. pp. 2960-2972.

Nielsen JG. 1986. Scophthalmidae. In: Whitehead PJP, Bauchot M-L, Hureau J-C, Nielsen J and Tortonese E. (eds). Fishes of the North-eastern Atlantic and the Mediterranean. UNESCO. pp 1287-1293.

Pethon P. 2005. Aschehougs store fiskebok. Aschehoug. 468 p.

Risso A. 1810. Ichthyologie de Nice, ou histoire naturelle des poissons du Département des Alpes Maritimes. F. Schoell, Paris. i-xxxvi + 1-388, Pls. 1-11.

Robson SM, King PA, Hannan J, McGrath D. 2000. Age and growth of a sample of four-spot megrim, Lepidorhombus boscii, from off the west coast of Ireland. Biology \& Environment: Proceedings of the Royal Irish Academy 100B: 143-148.

Robson SM, King PA, McGrath D. 2005. The morphometric and meristic characteristics of common megrim Lepidorhombus whiffiagonis and four-spot megrim Lepidorhombus boscii from off the west coast of Ireland. The Irish Naturalists' Journal 28: 116-119.

Sánchez F, Pérez N, Landa J. 1998. Distribution and abundance of megrim (Lepidorhombus boscii and Lepidorhombus whifffiagonis) on the northern Spanish shelf. ICES Journal of Marine Science 55: 494-514. doi: 10.1006/jmsc.1997.0279

Velasco F, Heessen H, Rijnsdorp A, de Boois I. 2015. Turbots (Scophthalmidae). In: Heessen HJL, Daan N and Ellis JR. (eds). Fish atlas of the Celtic Sea, North Sea, and Baltic Sea. Wageningen Academic Publishers. pp. 429-446.

Walbaum JJ. 1792. Petri Artedi sueci genera piscium. In quibus systema totum ichthyologiae proponitur cum classibus, ordinibus, generum characteribus, specierum differentiis, observationibus plurimis. Redactis speciebus 242 ad genera 52. Ichthyologiae pars III. Ant. Ferdin. Rose, Grypeswaldiae. Part 3: i-viii + 1-723, Pls. 1-3.

\section{Editorial responsibility: Torkild Bakken.}

This article is open-access and distributed under the terms of the Creative Commons Attribution 4.0 International license. This permits all non-commercial use, distribution, and reproduction in any medium, provided the original work is properly cited.

(http://creativecommons.org/licenses/by/4.0/). 